will be set up at the other sites under consideration, and each site will probably be occupied several times for periods of about two weeks at any one time.

\section{Russian Journal of Inorganic Chemistry}

STARTING with the January 1959 issue, the Chemical Society is to publish, with the support of the Department of Scientific and Industrial Research, a cover-to-cover translation of the monthly journal, Zhurnal neorganicheskoi Khimii, a publication of the Academy of Sciences of the U.S.S.R. The translation will be undertaken for the Society by Infosearch, Ltd., and the Society has appointed Prof. P. L. Robinson as executive editor. He will be assisted by an advisory panel of distinguished inorganic chemists. The sale and distribution of the journal will be undertaken by Cleaver-Hume Press, Ltd., 31 Wright's Lane, London, W.8, from whom a detailed prospectus giving the scope of this journal may be obtained. Translations will be issued in monthly parts as soon as possible after the Russian original is available. The subscription rate will be $£ 30$ (United States, 90 dollars) per annum, but universities and technical colleges may subscribe at a discount of 25 per cent. Single issues can be purchased at $£ 4$ ( 12 dollars) per copy. The Society also hopes to start the publication within the next year of translations of the Russian Journal of Physical Chemistry (Zhurnal fizicheskoi Khimii) and Progress in Chemistry (Uspekhi Khimii).

\section{School Mathematics}

USEFUI comments on the teaching of mathematics in schools are to be found in the Spring 1959 issue of Forum (1, No. 2). The headmaster of a junior school, the head of the mathematics depart. ment at a comprehensive school and a university professor of mathematics all agree that the aversion to mathematics which is found in so many intelligent adults was implanted in the primary school. Accord. ing to one observer, mathematics in the primary school consists entirely of computation. "Available text-books present dreary, intelligible masses of sums instead of challenging children to think, to reflect on how, when and where, with numbers and space relationships." Instead of imparting an appreciation of number relationships in the way advocated by Piaget, most mathematics teaching in primary schools consists of a series of tricks which have little connexion with the life of the child. Suggestions for making the teaching more related to the child's experience are described in two of the articles, while Prof. R. L. Goodstein, of the University of Leicester, also advocates research to find a more enlivening syllabus and more successful methods of presentation.

\section{Control of Exhaust Fumes}

IN reply to a question in the House of Commons on March 24 regarding research into the control of the emission of diesel oil and petrol exhaust fumes from vehicles, Mr. H. Nicholls said that the results of work on combustion in diesel and petrol engines, carried out by the Motor Industry Research Association and the British Internal Combustion Engine Research Association and elsewhere, showed that the greater part of the smoke from such engines could be prevented by proper adjustment, running and maintenance. The Warren Spring Laboratory of the Department of Scientific and Industrial Research had tested a catalytic device which effectively reduced the pollution from petrol engine fumes. Mr. Nicholls agreed that unpleasant fumes were often due to absence of proper maintenance.
National Research Development Corporation of India

THe fourth annual report of the National Research Development Corporation of India, which includes the statement of accounts for the period ending March 31, 1958 (pp. 20. New Delhi : National Research Development Corporation of India, 1958), records 59 inventions reported for development by eighteen research institutions and individuals, making a total of 447. Five new patent applications were filed and seventeen new licence agreements were negotiated. New projects for refining cotton seed oil, for white cement from feldspar, and for a fluidized. bed technique for textile processing were instituted, and a project for pine oil from Indian turpentine was completed. Progress is reported in those for production of phthalic anhydride by fluidized-bed oxidation of coal tar oils, for copper chlorophyll, for bamboo mechanical pulp, the de-ionization of sugar cane juice and for a thermoelectric generator.

\section{The Civic Trust}

Founded just over a year ago to ensure that community developments are made with good taste and dignity and to give delight to all inhabitants, the Civic Trust has already acquired a momentum which should lead to a future of promise and fulfilment. In collaboration with the B.B.C. Television Service, four useful films have been produced showing how the Trust is waging war on ugliness. The threatened demolition of part of the Close of Dunblane Cathedral has been averted by prompt intervention by the Trust. As the first of a series of 'live' experiments, Magdalen Street, Norwich, is being redecorated in accordance with an over-all scheme prepared by the Trust. The Trust is also to develop a system of amenity awards, the objects of which are to encourage good local architecture and building of all kinds which can be said to make a desirable contribution to the civic and rural scene as a whole, and to stimulate interest in all other types of physical development. Details of the awards can be obtained from the Civic Trust, 79 Buckingham Palace Road, London, S.W.I.

\section{South Australian Museum}

THE most recent issue of the Records of the South Australian Museum (13, No. 2; 1958) forms another sumptuous part of the current volume, with 156 pages of text and twenty-four excellent plates. Most of the papers are by members of the staff of the South Australian Museum and include contributions on the aboriginal cave paintings at Sleisbeck, a revision of the ghost moths, new cretaceous fossils from New Guinea, Australian beetle-mimicking bugs of the family Lygaeidae, and on the Potoroinea (a group of central Australian mammals). Such a publication gives evidence of a progressive museum with a staff undertaking research of a high order.

\section{Aviation Psychology}

THE military Air Forces and civilian air lines of every country are aware of the many psychological factors involved in safe flying, and of the difficulties in selecting and training suitable air-crew. But only in the United States and, to a lesser extent, in Britain are there sufficient psychologists employed in the field of aviation to develop a systematic attack on these problems. Thus in an attempt to co-ordinate and further their activities, the aviation psychologists of Western European countries have formed an association; and a recent monograph (Aviation 